\title{
PENGALAMAN ODHA REMAJA TENTANG PENATALAKSANAAN HIV/AIDS DI KOTA SEMARANG
}

\author{
Rose Nur Hudhariani ${ }^{1}$, Linda Ratna Selfia ${ }^{2}$, M. Jamaluddin ${ }^{3}$ \\ ${ }^{1,2,3}$ STIKes Karya Husada Semarang \\ Email :rose.djogja@gmail.com
}

\begin{abstract}
ABSTRAK
Tingginya kasus HIV/AIDS pada remaja di Jawa-Tengah dikarenakan jumlah penduduk di pulau Jawa adalah merupakan jumlah penduduk terbesar di Indonesia. Berdasarkan sensus penduduk yang terakhir pada tahun 2000 diperkirakan jumlah penduduk mencapai lebih dari 250 juta dan sebagian besar penduduk Indonesia hidup di pulau Jawa (59\%) salah satunya Semarang. Tujuan Penelitian ini utuk mengetahui pengalaman ODHA remaja dalam penatalaksanaan HIV/AIDS di kota Semarang. Jenis Penelitian ini adalah Kualitatif, partisipan utama adalah remaja dengan HIV. Kasus HIV/AIDS tertinggi di kota Semarang terjadi pada kasus remaja. Berdasarkan pengalaman ODHA maka sifat dan sikap ODHA adalah tergantung dari berapa lama ODHA terpantau oleh lembaga-lembaga yang menaunginya. Semakin lama terpantau maka semakin membuat ODHA bisa menjaga dirinya dengan baik dalam segala hal. Dinas Kesehatan Kota Semarang dalam proses penetuan kebijakan dan strategi untuk mendukung berbagai program terkait HIV/AIDS, sebagai bahan acuan LSM untuk semakin bisa merangkul ODHA remaja agar bisa membuat hidup mereka memiliki arti lebih dalam masyarakat
\end{abstract}

Kata Kunci $\quad$ : HIV/AIDS; remaja dan ODHA; penatalaksanaan

\section{EXPERIENCES OF ADOLESCENT PLACING IN HIV/AIDS IN THE MANAGEMENT OF HIV/AIDS IN SEMARANG CITY}

\begin{abstract}
The high number of HIV / AIDS cases in adolescents in Central Java because the population in Java is the largest population in Indonesia. Based on the last population census in 2000 it is estimated that the population reaches more than 250 million and the majority of Indonesia's population lives on Java (59\%) one of them is Semarang. To know the experience of PLWHA in management of HIV / AIDS in Semarang city. This Research Type is Qualitative. The highest HIV / AIDS cases in Semarang occurred in adolescent cases. Based on the experience of ODHA, the nature and attitude of PLHIV is dependent on how long PLHIV observed by the institutions that shelter it. The longer observed, the more ODHA can keep themselves well in everything. Teenagers can maintain good and healthy association in order not to accrue more cases of adolescent PLHIV in Semarang City is increasing.
\end{abstract}

Keywords : HIV/AIDS; adolescents and behavior of teenagers. 


\section{Pendahuluan}

Perkembangan infeksi di seluruh dunia oleh Human Immunodeficiency Virus (HIV) dan Acquired Immune Deficiency Syndrome (AIDS) dalam tahapan membahayakan, dengan jumlah penderita yang terus meningkat (WHO,2014). Tingginya kasus HIV/AIDS pada remaja di JawaTengah dikarenakan jumlah penduduk di pulau Jawa adalah merupakan jumlah penduduk terbesar di Indonesia. Berdasarkan sensus penduduk yang terakhir pada tahun 2000 diperkirakan jumlah penduduk mencapai lebih dari 250 juta dan sebagian besar penduduk Indonesia hidup di pulau Jawa (59\%) salah satunya Semarang

Proporsi kasus HIV/AIDS tertinggi teridentifikasi terjadi pada kelompok umur 16-23 tahun (47,2\%), disusul kelompok umur 25-40 tahun (31,39\%) dan kelompok umur 40-50 tahun (9,5\%) (Depkes, 2011). Di kota Semarang jumlah kasus HIV/AIDS yang sudah tercatat adalah sebanyak 706 kasus dengan penderita terbanyak adalah pada remaja dengan kejadian sebanyak 249 kasus. Dalam kaitannya dengan hal tersebut, disini peran pemerintah dan LSM yang berpengaruh terhadap kondisi ini.pemerintah dengan cara menggandeng LSM melakukan beberapa kegiatan-kegiatan yang bertujuan untuk meningkatkan taraf derajat kesehatan ODHA (Orang Dengan HIV/AIDS) remaja. Pendanaan dalam setiap kegiatan itu adalah dari alokasi dana pemerintah dan dinas kesehatan setempat dan LSM serta dari sumbangan beberapa donatur yang telah bersedia memberikan dana dalam setiap kegiatan tersebut. Adapun kegiatan yang rutin dalam rangka merangkul dan juga pembinaan ODHA remaja diantaranya adalah dengan melakukan jalan sehat, penyuluhan, bakti sosial dan juga cek kesehatan gratis.

\section{Tinjauan Teoritis}

HIV (Human Immunodeficiency Virus) yaitu sejenis virus yang menyerang sistem kekebalan tubuh manusia. Virus HIV masuk ke dalam sel darah putih dan merusaknya sehingga sel darah putih yang befungsi sebagai pertahanan terhadap infeksi akan menurun jumlahnya. Akibatnya sistem kekebalan tubuh menjadi lemah dan penderita mudah terkena berbagai macam penyakit ( Robbins,2012)

HIV adalah singkatan dari Human Immunodeficiency Virus yang dapat menyebabkan AIDS dengan cara menyerang sel darah putih yang bernama sel CD4 sehingga dapat merusak sistem kekebalan tubuh manusia yang pada akhirnya tidak dapat bertahan dari gangguan penyakit walaupun yang sangat ringan sekalipun. HIV menyerang sel CD4 dan merubahnya menjadi tempat berkembang biak HIV baru kemudian merusaknya sehingga tidak dapat 
digunakan lagi. Sel darah putih sangat diperlukan untuk sistem kekebalan tubuh. Tanpa kekebalan tubuh maka ketika diserang penyakit maka tubuh kita tidak memiliki pelindung. Dampaknya adalah kita dapat meninggal dunia terkena pilek biasa (Hutapea, 2011)

AIDS (Acquired Immune Deficiency Syndrome) yaitu kumpulan gejalapenyakit (syndrom) yang didapat akibat turunnya kekebalan tubuh yang disebabkan oleh HIV (Robbins, 2013). Dalam bahasa Inggris orang yang terinfeksi HIV/AIDS disebut PLWHA (People Living with HIV/AIDS), sedangkan di Indonesia kategori ini diberi nama ODHA (Orang dengan HIV/AIDS) .

ODHA atau orang dengan HIV/AIDS merupakan orang yang menderita HIV/AIDS yang seacara fisik sama dengan kita yang tidak menderita HIV/AIDS. Mereka pada umumnya memiliki cirri-ciri yang sama seperti orang yang sehat sehingga tidak dapat dietahui apakah seseorang itu menderita HIV/AIDS atau tidak

\section{Metode Penelitian}

Jenis penelitian ini adalah penelitian kualitatif, dengan pendekatan induktif menggunakan pendekatan fenomenologi. Penelitian dilakukan di LSM Graha Mitra pada bulan Januari 2018. Peneliti bekerjasama dengan LSM Graha Mitra untuk memilih informan, agar sesuai dengan karakteristik yag diinginkan oleh peneliti. Peneliti melakukan wawancara mendalam (indept interview) pada informan dengan menggunakan alat bantu rekam yaitu handphone. Informan pada penelitian ini adalah remaja dengan HIV/AIDS yang tinggal di Kota Semarang dan Informan triangulasi adalah teman dekat informan yang selama ini selalu menjadi tempat curhat informan, ketua LSM Graha Mitra dan Kepala Dinas Kesehatan Kota Semarang.

\section{Hasil Penelitian}

1. Upaya yang dilakukan ODHA remaja dalam rangka menjaga kesehatan dirinya.

Pada ODHA remaja yang telah terpantau oleh LSM dan belum terpantau oleh LSM memiliki perbedaan yaitu antara lebih terbuka dan juga masih sangat tertutup. Dimana ODHA yang sudah terpantau oleh LSM memiliki proses yang lebih baik dalam hal menjaga kesehatan dirinya karena sudah memahami benar tentang virus yang sudah merasuk di tubuhnya sehingga ODHA yang sudah terpantau oleh LSM sangat memiliki rasa kesadaran diri yang sangat baik. Tingkat kepatuhan dalam mengkonsumsi obat pun berjalan dengan baik karena memiliki rasa kesadaran yang tinggi

2. Hambatan ODHA remaja dalam rangka menjaga kesehatan dirinya. 
Hambatan tiap kasus merupakan suatu hal yang sering ditemui. Akan tetapi dalam kaitannya dengan HIV/AIDS, disini sangat ditentukan oleh kualitas kesadaran dari masing-masing individu yang sangat berbeda dan beraneka ragam dan tidak jarang disini peran pendamping (LSM) justru yang paling berpengaruh dalam hal membangun mental dan juga untuk membangun semua bakat dan juga penyalur bakat sehingga ODHA tidak dipandang sebelah mata oleh sekelompok orang tertentu. Dalam kaitannya pula dengan hal ini maka ada beberapa hal yang terkadang menjadi hambatan, yaitu selain tingkat kesadaran diri, maka proses obat turun dari pemerintah yang terkadang telat yang lebih sering dikarenakan oleh medan yang ditempuh dalam proses pengiriman obat tersebut, sehingga obat telat datang.

3. Kurangnya kesadaran diri dalam meminum obat.

Yaitu terdapat banyak sekali hambatan dalam kasus HIV/AIDS. Akan tetapi dalam kaitannya dalam kasus ini yang sering terjadi adalah dalam segala proses dan bentuk kesadaran individu ynag masing-masing berbeda dan tidak bisa di sama ratakan. Hal ini yang menjadi hambatan paling besar sebenarnya

4. Upaya yang dilakukan pemerintah dalam proses menurunkan kejadian HIV/AIDS di kota Semarang.

Program dan upaya yang dilakukan pemerintah dalam proses menurunkan kejadian HIV/AIDS di kota Semarang adalah skreening gratis dalam kasus HIV/AIDS, pengobatan ARV (Anti-Retroviral) gratis, penyuluhan, seminar dan juga masih banyak sekali kegiatan lain yang merupakan suatu upaya pemerintah guna penurunan angka kejadian HIV/AIDS

5. Hambatan pemerintah dalam proses menurunkan kejadian HIV/AIDS di kota Semarang.

Menganut pada sistem pendataan ODHA, sistem distribusi obat dan juga proses penyuluhan yang terkadang sulit diterima oleh ODHA baru yang mungkin baru sebentar atau bahkan belum pernah dikawal oleh LSM mengenai perkembangan dan juga semua bentuk motivasi hidup untuk ke arah yang lebih baik.

\section{Pembahasan}

Para informan yang terjangkit HIV sudah memiliki kesadaran dalam pola hidup dan memiliki semangat hidup yang luar biasa, mereka berprestasi dalam bidangnya masing-masing. Akan tetapi untuk ODHA baru yang belum lama terpantau oleh LSM (Lembaga Swadaya Masyarakat) disitu peran mereka masih sangat kurang dan cenderungmenutup diri (introvert) dikarenakan masih membutuhkan proses penyesuaian diri yang tepat. Semua program dari LSM (Lembaga Swadaya Masyarakat) sudah 
berjalan dengan baik dan lancar, akan tetapi hambatannya adalah mengenai kesadaran diri untuk ODHA yang baru terdeteksi HIV itu masih sangat kurang.

1. Upaya yang dilakukan ODHA remaja dalam rangka menjaga kesehatan dirinya.

Penentuan penatalaksanaan yang sangat tepat adalah dengan memulai terapi obat anti retroviral (ART) dan juga dengan olahraga serta mengkonsumsi makanan yang sehat dan bergizi (Dempsey,2012). Hal ini harus dilakukan mengingat kesehatan dalam kondisi tubuh ODHA merupakan suatu hal yang teramat penting dan tidka bisa disepelekan. Akan tetapi tingkat kesadaran diri ODHA tersebut lah yang memengaruhi tentang bagaimana cara ODHA teratur atau tidak dalam mengkonsusi obat-obatan tersebut( Dempsey, 2012).

Hasil penelitian dalam jurnal "Pengetahuan HIV dan AIDS di Indonesia" oleh Sudikno, Bona Simanungkalit dan Siswanto, jika tingkat menjaga kesehatan tiap ODHA adalah berbedabeda, yakni tergantung bagaimana peola dan tingkat lama atau tidaknya ODHA tersebut dibawah naungan LSM. Sehingga antara yang sudah terpantau dan yang belum terpantau keduanya memiliki perbedaan dalam hal kesadaran diri untuk menjaga diri, menjaga kesehatan dan juga pola pikirnya tentang arti kesehatan dirinya sendiri.

2. Hambatan ODHA remaja dalam rangka menjaga kesehatan dirinya.

Bebeberapa hambatan ODHA dalam pelaksanaan upaya pencegahan HIV/AIDS di Indonesia yang dapat diidentifikasi sebagai berikut(Nursalam, 2007) 1)Keterbatasan sumber daya manusia dan sarana, 2)Pengobatan masih memiliki banyak masalah, 3) Adanya koinfeksi dengan Hepatitis $\mathrm{C}$ semakin meningkatkan risiko timbulnya komplikasi penyakit hati, selain karena terjadi infeksi pada hati itu sendiri juga akibat interaksi pengobatan Hepatitis C dengan HIV. Ribavirin, misalnya, dapat menyebabkan anemia, sehingga dalam hal ini zidovudin sebaiknya diganti dengan stavudin. Interferon juga dapat menekan limfosit, sehingga harus benar-benar diperhatikan pemberiannya pada odha dengan melihat jumlah CD4, 4) Kurangnya kesadaran diri dalam meminum obat Yaitu terdapat banyak sekali hambatan dalam kasus HIV/AIDS. Akan tetapi dalam kaitannya dalam kasus ini yang sering terjadi adalah dalam segala proses dan bentuk kesadaran individu yang masing-masing berbeda dan tidak bisa di sama ratakan. Hal ini yang menjadi hambatan paling besar sebenarnya.

Penelitian dalam jurnal "Pengetahuan HIV pada Remajadi Desa Bulusan Kecamatan Kalipuro Kabupaten Banyuwangi” oleh Marya Sofa yang telah menuliskan tentang hambatan yang ditemui dalam kasus ODHA Remaja adalah tentang cara mengenali diri, potensi diri dan juga kaitannya dalam proses meminum obat (kepatuhan minum obat) serta tentang telatnya pemasokan obat ARV (Anti-Retroviral) yang dikarenakan oleh lokasi tiap daerah yang terkadang sulit dijangkau sehingga obat yang dikirim oleh pemerintah sering telat datang.

3. Dukungan dari berbagai pihak yang berkaitan dalam kasus HIV/AIDS. 
Dukungan dari bergabai pihak, disini semua sangat berperan penting. Tidak hanya Dinas Kesehatan, Rumah Sakit, LSM (Lembaga Swadaya Masyarakat) dan juga Puskesmas, namun disini segala bentuk peran dari masyarakat, teman sebaya dan juga lingkunganpun sangat mendukung dan sangat memengaruhi segala proses penyesuaian dan juga pembentukan mental bagi ODHA(Nursalam,2007).

Penelitian dalam jurnal : "Peranan Perilaku Pengetahuan dan Sikap HIV Remaja Pranikah" oleh Marya Sofa yang membahas tentang ketiga kaitan dukungan dalam masalah kasus HIV/AIDS, yaitu dukungan oleh pemerintah, teman sebaya dan juga lingkungan. Dengan demikian antara hal tersebut memang sangat erat berkaitan dan saling berkesinambungan satu sama lain.

4. Upaya yang dilakukan pemerintah dalam proses menurunkan kejadian HIV/AIDS di kota Semarang.

Peran pemerintah sangat berpengaruh sekali dimana semua program adalah berawal dari pemerintah. Begitupun juga tentang semua pemasokan obat-obatan. Sehingga pemerintah sangat memegang peranan penting yang harus dilakukan. Ada beberapa hal yang dapat dilakukanpemerintah untuk mencegah semakin banyaknya kasus HIV/AIDS, yaitu(KPA,2008) :

Untuk mengatasi masalah kesehatan termasuk penyakit HIV/AIDS di kenal tiga tahap pencegahan,Pencegahan primer: promosi kesehatan (health promotion) dan perlindungan khusus (specific protection). Pencegahan sekunder: diagnosis dini dan pengobatan segera (early diagnosis and prompt treatment), dan pembatasan cacat (disability limitation). Pencegahan tersier: rehabilitasi.

Pencegahan primer dilakukan pada masa individu belum menderita sakit, upaya yang dilakukan ialah a) Promosi kesehatan/health promotion yang ditujukan untuk meningkatkan daya tahan tubuh terhadap masalah kesehatan, seperti gaya hidup yang lebih sehat dengan berolah raga, b) Perlindungan khusus (specific protection): upaya spesifik untuk mencegah terjadinya penularan penyakit HIV/AIDS, seperti penggunaan kondom, tidak berganti-ganti pasangan seks, dll seperti konsep $A B C D E$ yang direkomendasika oleh WHO sebagai berikit :

a) Abstinent

Artinya tidak melakukan hubungan seksual. Mayoritas infeksi HIV berasal dari hubungan seksual tanpa pelindung antar individu yang salah satunya terkena HIV. Hubungan homoseksual merupakan salah satu faktor resiko infeksi HIV/AIDS. Abstinent merupakan salah satu poin dalam seks aman yang memberikan solusi agar terhindar dari HIV/AIDS dengan tidak berhubungan seks, meskipun sebenarnya hal Jurnal SMART Kebidanan Sekolah Tinggi Ilmu Kesehatan (STIKes) Karya Husada Semarang www.stikesyahoedsmg.ac.id/ojs/index.php/sjkb 
ini tidaklah mudah sebab mengingat salah satu kebutuhan biologis manusia adalah seks.

b) Be faithful

Artinya melakukan hubungan seks dengan pasangan saja. Be faithful lebih didasari dengan kesetiaan terhadap pasangan, tidak berganti-ganti pasangan seks yang dapat meningkatkan resiko tertular HIV/AIDS. Oleh karena itu, sebenarnya penting bagi mereka untuk menangguhkan aktifitas seks sampai mereka menemukan pasangan yang dapat diyakini untuk menjalani hubungan jangka panjang dan didasari karena kesetiaan.Be faithful akan mengurangi resiko tertular HIV. Di Uganda antara melaporkan $20 \%$ penurunan mitra seks sejalan dengan $11 \%$ penurunan kasus HIV.

c) Condom

Kondom oleh WHO diakui memiliki keefektifan yang tinggi dalam mencegah transmisi HIV dan AIDS jika digunakan secara benar dan konsisten. Kegagalan kondom biasanya disebabkan oleh penggunaan yang tidak benar atau tidak konsisten selain disamping karena kerusakan ataupun kadaluarsa.

d) Drugs

Artinya tolak penggunaan NAPZA. Laporan AIDS di Asia, yang didukung oleh Asian Development Bank dan dikoordinasikan dengan Joint United Nations Programme on HIV and AIDS (UNAIDS), memperingatkan bahwa pengguna narkoba, bertanggung jawab untuk peningkatan jumlah infeksi HIV di banyak negara di Asia. Risiko lebih lanjut terletak pada prevalensi tingi penggunaan narkoba nonsuntik, seperti amphetamine stimulan, dimana pengguna sering terlibat dalam perilaku yang menimbulkan risiko tinggi infeksi HIV, terutama melalui hubungan seks, serta konsumsi obat-obatan yang tentunya sangat berisiko terhadap kesehatan, apalagi kecenderungan berganti-ganti pasangan lebih mudah dilakukan dalam kondisi hubungan seks yang diselingi dengan minuman dan narkoba yang tertunya berdampak pada resiko penularan HIV/AIDS(Syahlan, 2013).

e) Equipment

Artinya hindari tindik dan tato di tubuh, karena seringkali sebelum jarum digunakan untuk mentato/menindik seseorang yang sehat, alat itu telah dipakai pada seseorang yang terkena penyakit menular yang salah satunya HIV.Penelitian dalam jurnal "Hubungan Karakteristik Remaja Terkait Resiko Penularan HIV/AIDS dan Perilaku Seks Tidak Aman di Indonesia” oleh Niniek Lely Lestari dan Heri Basuki. 
Jika dukungan pemerintah sangat mengambil peran yang banyak dalam hal ini. Semua terkait program pemerintah sangat memegang peranan penting dalam rangka meningkatkan kualitas hidup ODHA. Sehingga semua program tentang HIV/AIDS dapat terlaksana dan berjalan dengan baik dan juga lancar.

5. Hambatan pemerintah dalam proses menurunkan kejadian HIV/AIDS di kota Semarang.

Bebeberapa hambatan dalam pelaksanaan upaya pencegahan HIV/AIDS di Indonesia yang dapat diidentifikasi sebagai berikut(Nursalam, 2007) :

a. Kepemimpinan yang lemah. Diperlukan kepemimpinan di yang kuat, khususnya di tingkat pemerintah. Aspek kepemimpinan yang utama dalam penanggulangan HIV/AIDS adalah komitmen pribadi dan tindakan nyata.

b. Kelemahan dalam perencanaan strategik serta rendahnya kemampuan dalam pendataan hasil yang dicapai. Beberapa rencana strategik perlu memuat parameter capaian yang harus dicapai dalam kerangka waktu tertentu.

c. Pendataan. Dalam hal ini diperlukan pendataan yang akurat, baik mengenai upaya yang dikerjakan oleh berbagai instansi pemerintah, universitas, LSM, maupun badan donor dan rincian hasilnya.

d. Kurangnya mekanisme koordinasi yang efektif dan efisien antar pihak yang melakukan upaya pencegahan HIV/AIDS.

e. Keterbatasan sumber daya manusia dan sarana.

f. Pengobatan masih memiliki banyak masalah.

g. Adanya koinfeksi dengan Hepatitis $\mathrm{C}$ semakin meningkatkan risiko timbulnya komplikasi penyakit hati, selain karena terjadi infeksi pada hati itu sendiri juga akibat interaksi pengobatan Hepatitis C dengan HIV. Ribavirin, misalnya, dapat menyebabkan anemia, sehingga dalam hal ini zidovudin sebaiknya diganti dengan stavudin. Interferon juga dapat menekan limfosit, sehingga harus benarbenar diperhatikan pemberiannya pada odha dengan melihat jumlah CD4.

h. Kurangnya kesadaran diri dalam meminum obat.

i. Keterbatasan jenis ARV dan belum tersedianya obat-obat lini kedua, serta belum tersedianya layanan tes resistensi terhadap ARV.

j. Hasil penelitian dalam jurnal "Pengetahuan HIV dan AIDS di Indonesia" oleh Sudikno, Bona Simanungkalit dan Siswanto. Dari semua hambatan disini yang paling mencolok adalah bukan lagi tentang obat yang terlambat turun, akan tetapi soal kesadaran diri masing-masing ODHA yang berbeda. Kita tidak bisa 
menyamakan antar ODHA satu dengan ODHA yang lain. Karena mereka memiliki karakteristik yang berbeda. Maka disini peran semua lingkup terkait sangat dibutuhkan guna kualitas hidup ODHA yang akan menjadi lebih baik.

\section{Kesimpulan}

1. ODHA dalam proses menjaga dirinya sudah sangat mengerti tentang bagaimana cara yang baik dan benar. Peran dari LSM (Lembaga Swadaya Masyarakat) sangat berpengaruh guna mengawal segala tindakan dan langkah untuk ODHA guna peningkatan kualitas hidup ODHA dan juga tentang berbagai prestasi ODHA yang mungkin masih bisa dikembangkan.

2. ODHA menjaga kesehatan diri memiliki masalah yang paling sering muncul yaitu kurang istirahat dan terlambat makan, Itu yang menyebabkan ODHA jatuh sakit. Akan tetapi ODHA disini sudah sangat mengerti tentang bagaimana cara yang baik dan benar untuk menjaga kesehatannya.

3. Dinas Kesehatan, Puskesmas, LSM (Lembaga Swadaya Masyarakat), masyarakat dan juga berbagai bentuk elemen organisasi lain saling berhubungan erat dengan ODHA merupakan suatu hal yang saling berkaitan dan merupakan suatu kesatuan yang utuh guna meendukung ODHA agar semakin banyak yang tetlibat maka akan semakin berhasil pula segala bentuk dan juga proses kerja guna memotivasi hidup ODHA dan juga demi kelangsungan hidup ODHA agar menjadi lebih baik serta akan semaki berkurang penderita HIV/AIDS per tiap tahunnya.

4. Program dan upaya yang dilakukan pemerintah dalam proses menurunkan kejadian HIV/AIDS di kota Semarang adalah skreening gratis dalam kasus HIV/AIDS, pengobatan ARV (Anti-Retroviral) gratis, penyuluhan, seminar dan juga masih banyak sekali kegiatan lain yang merupakan suatu upaya pemerintah guna penurunan angka kejadian HIV/AIDS.

5. Hambatan yang dialami pemerintah dalam proses menurunkan kejadian HIV/AIDS terkadang adalah adanya medan yang berbeda di setiap daerah yang dapat berimbas pada telatnya obat ARV (Anti-Retroviral) yang telat datang ke masing-masing rumah sakit sehingga akibatnya ODHA melakukan transaksi pinjam-meminjam obat kepada ODHA lain yang kemudian akan diganti ketika ODHA sudah mendapatkan obat dari rumah sakit tersebut. 


\section{Saran}

Dinas Kesehatan Kota Semarang dalam proses penetuan kebijakan dan strategi untuk mendukung berbagai program terkait HIV/AIDS, sebagai bahan acuan LSM untuk semakin bisa merangkul ODHA remaja agar bisa membuat hidup mereka memiliki arti lebih dalam masyarakat.

\section{Referensi}

WHO, (2015). Human Immunodeficiency Virus (HIV) dan Acquired Immune Deficiency Syndrome (AIDS).

Departemen Kesehatan RI, (2015). Laporan Informasi HIV/AIDS Pada Kelompok Umur. Jakarta ; Sub Bagian Penyakit Menular dan Tidak Menular PP\&PL.

Robbins, dkk. (2013). Dasar Patologi Penyakit, Edisi 5. Jakarta : EGC.

Hutapea, R. (2011). AIDS, PMS danPerkosaan. Jakarta : Rineka Cipta.

Family Health Internasional. (2009). HIV/AIDS Virus. Jakarta : EGC.

Komisi Penanggulangan AIDS Nasional. (2008). Strategi Komunikasi Penanggulangan HIV dan AIDS di Indonesia. Jakarta : KPAN.

Nursalam (2011). Epidemiologi dan Penyakit Menular. Jakarta : Salemba Medika.

Hakim. (2010). Pengantar HIV/AIDS. Jakarta : EGC.

Syahlan. (2011). AIDS dan Penanggulangan. Jakarta : Studio Driya Media.

Widiyono. (2011). Penyakit Tropis, Epidemiologi, Penularan, Pencegahan \& Pemberantasannya, Edisi Kedua. Jakarta : Erlangga

Dempsey. (2012). Riset Keperawatan. Buku Ajar dan Latihan, Edisi 4. Jakarta : EGC.

Syahlan. (2013). AIDS dan Penanggulangan. Jakarta : Studio Driya Media.

Wartono. (2011). AIDS Dikenal Untuk Dihindari. Jakarta : Lembaga Pengembangan Informasi Indonesia.

Nursalam. (2011). Asuhan Keperawatan pada Pasien Terinfeksi HIV/AIDS. Jakarta : Salemba Medika.

Sunarto. (2014). Pengantar Ilmu Sosiologi. Jakarta : Fakultas Ekonimi Universitas Indonesia.

Notoatmodjo. (2018). Metodologi Penelitian Kesehatan. Jakarta PT. Rineka Cipta. 